\title{
Correction to: Are shocks to human capital composition permanent? Evidence from the Mariel boatlift
}

\author{
Seung-hun Chung ${ }^{1} \cdot$ Mark D. Partridge $^{1}$
}

Published online: 31 October 2019

(C) The Author(s) 2019

\section{Correction to: The Annals of Regional Science https://doi.org/10.1007/s00168-019-00938-7}

The original version of this article was revised due to a retrospective Open Access order.

The article Are shocks to human capital composition permanent? Evidence from the Mariel boatlift, written by Seung-hun Chung and Mark D. Partridge, was originally published electronically on the publisher's internet portal (currently SpringerLink) on 27 August 2019 without open access.

With the author(s)' decision to opt for Open Choice, the copyright of the article changed on 22 October 2019 to (C) The Author(s) 2019 and the article is forthwith distributed under the terms of the Creative Commons Attribution 4.0 International License (http://creativecommons.org/licenses/by/4.0/), which permits use, duplication, adaptation, distribution and reproduction in any medium or format, as long as you give appropriate credit to the original author(s) and the source, provide a link to the Creative Commons license and indicate if changes were made.

Open Access This article is distributed under the terms of the Creative Commons Attribution 4.0 International License (http://creativecommons.org/licenses/by/4.0/), which permits unrestricted use, distribution, and reproduction in any medium, provided you give appropriate credit to the original author(s) and the source, provide a link to the Creative Commons license, and indicate if changes were made.

Publisher's Note Springer Nature remains neutral with regard to jurisdictional claims in published maps and institutional affiliations.

The original article can be found online at https://doi.org/10.1007/s00168-019-00938-7.

Mark D. Partridge

partridge.27@osu.edu

Seung-hun Chung

chung.627@osu.edu

1 The Ohio State University, 2120 Fyffe Road Columbus, Columbus, OH 43210, USA 